\title{
Propolis in the control of bacterial bovine mastitis: a tool for the production of organic milk
}

\section{Própolis no controle de mastite bovina bacteriana: uma ferramenta para a produção de leite orgânico}

\author{
Gabriel Michelutti do Nascimento ${ }^{1 *}$; Marita Vedovelli Cardozo2; Mylena Karoline \\ Valmorbida3; Natália Pereira4; José Carlos Barbosa5; Flávio Rubens Favaron \\ Junior6; Fernando Antônio de Ávila7
}

Highlights

Natural antiseptic based on propolis promoted had an antibacterial effect.

Greatly reduced concentrations of Enterobacteriaceae and Staphylococcus spp. in vivo.

lodine-free compound neither compromised equipment nor harmed the skin.

\begin{abstract}
Bovine mastitis is one of the main causes of economic damage in dairy farms. Therefore, the control and prevention of microorganisms involved in this disease, mainly Escherichia coli, Staphylococcus aureus, and Streptococcus agalactiae, are essential. One of the most important steps for the prevention of the disease is the use of antiseptic products before and after the milking process to avoid bacteria from infecting the udder of the animal. Currently, the most used antiseptic product in dairy farms is iodine-based, and organic dairy farms, which follow several strict regulations, including the use of natural products whenever possible, are often forced to adopt non-natural antiseptic products, such as iodine-based ones, because of the lack of natural alternatives. Propolis, a natural substance produced by honeybees, has been extensively studied for its various properties, one of which is antimicrobial activity. Therefore, a new natural antiseptic product containing $1 \%$ propolis in $10 \%$ hydroalcoholic solution for the pre-dipping, and $10 \%$ glycerol solution added with $0.2 \%$ citronella oil for the post-dipping was analyzed for its capacity to reduce bacteria in vivo in order to prevent bovine mastitis, allowing its use on organic dairy farms. A total of 128 samples were

1 Master's Student in Agropecuary Microbiology Graduate Program, Universidade Estadual Paulista Júlio de Mesquita Filho, Faculdade de Ciências Agrárias e Veterinárias, UNESP/FCAV, Jaboticabal, SP, Brazil. E-mail: gb.michelutti@ gmail.com

2 Profa in Veterinary Medicine Undergraduate Program, Universidade do Estado de Minas Gerais, UEMG, Passos, MG, Brazil. E-mail: maritavedovelli@gmail.com

${ }^{3}$ Master in Agropecuary Microbiology, UNESP/FCAV, Jaboticabal, SP, Brazil. E-mail: mylikarolyne15@gmail.com

4 Doctorate Student in Agropecuary Microbiology Graduate Program, UNESP/FCAV, Jaboticabal, SP, Brazil. E-mail: nataliavet16@hotmail.com

5 Prof. in Agronomy Graduate Program, UNESP/FCAV, Jaboticabal, SP, Brazil. E-mail: jc.barbosa@unesp.br

${ }^{6}$ Quality Control Analyst, EquineBasic, Belo Horizonte, MG, Brazil. E-mail: zoo2008@hotmail.com

7 Prof. in Agropecuary Microbiology Graduate Program, UNESP/FCAV, Jaboticabal, SP, Brazil. E-mail: f.avila@unesp.br

* Author for correspondence
\end{abstract}

Received: July 10, 2021 - Approved: Dec. 08, 2021 
analyzed in terms of bacterial growth for Enterobacteriaceae and Staphylococcus spp. using the spreadplate technique. The reduction in the bacterial concentration after the application of the products was compared between two antiseptic solutions, an iodine-based solution as the control and a propolis-based one as the natural alternative. The results obtained show a similar efficiency for both products in terms of total bacterial reduction, indicating considerable antimicrobial activity against bacteria most commonly associated with bovine mastitis. Molecular analysis was carried out for the identification of Streptococcus agalactiae; the PCR results were negative for the presence of $S$. agalactiae in all samples, indicating that the animals most likely did not have any form of the disease. The efficiency of the natural antiseptic was satisfactory, indicating an important find facilitating organic milk production worldwide, showcasing a natural antiseptic solution with efficient antimicrobial activity.

Key words: Biological control. Pest insects. Egg parasitoid. Enthomopatogenic fungi.

\section{Resumo}

A mastite bovina é uma das principais causas de prejuízo econômico na indústria leiteira, portanto o controle e prevenção de microrganismos envolvidos nessa doença, principalmente Escherichia coli, Staphylococcus aureus e Streptococcus agalactiae é essencial. Uma das principais etapas na prevenção dessa doença é o uso de produtos antissépticos antes e depois do processo de ordenha, a fim de evitar contaminação bacteriana no úbere do animal. Atualmente, o produto antisséptico mais utilizado na indústria leiteira é a base de iodo, e fazendas produtoras de leite orgânico, que precisam seguir uma série de regulações estritas, incluindo o uso de produtos naturais sempre que possível, são frequentemente forçadas a adotar antissépticos não-naturais, como os a base de iodo por falta de alternativas naturais. Própolis, uma substância natural produzidas por abelhas, tem sido extensivamente estudada por suas várias propriedades, sendo uma delas antimicrobiana. Portanto, um novo produto antisséptico natural contendo própolis à $1 \%$ em solução hidroalcóolica $10 \%$ para o pré-dipping, e glicerinada $10 \%$ adicionada de óleo de citronela à 0,2\% para o pós-dipping, foi avaliada quanto a sua capacidade de reduzir bactérias in vivo e prevenir a mastite bovina, além de poder ser utilizado na indústria leiteira orgânica. Um total de 128 amostras foram analisadas em termos de crescimento bacteriano para Enterobacteriaceae e Staphylococcus spp. utilizando a técnica de plaqueamento em superfície, a redução da concentração bacteriana após a aplicação dos produtos foi comparada entre duas soluções antissépticas, uma solução a base de iodo servindo como controle, e uma solução a base de própolis como a alternativa natural. Os resultados obtidos mostraram uma eficiência similar entre os produtos à base de iodo e própolis em termos de redução bacteriana total, indicando uma grande atividade antibacteriana contra as bactérias mais comumente associadas com a mastite bovina. Realizou-se análise molecular para a identificação de Streptococcus agalactiae, os resultados da PCR foram negativos para a presença de $S$. agalactiae em todas as amostras, indicando que os animais provavelmente não possuíam nenhuma forma da doença. A eficiência do antisséptico natural foi satisfatória, indicando um achado importante para auxiliar o crescimento da indústria de leite orgânico de forma mundial, mostrando uma solução antisséptica natural com atividade antimicrobiana eficiente.

Palavras-chave: Antisséptico. Mastite. Microrganismos. Natural. Própolis. 


\section{Introduction}

The milk industry has been growing worldwide, and consequently, dairy farmers are constantly searching for new products and methods to increase productivity. Along with this growth, the demand for organic products around the world is also increasing, including organic milk and dairy products.

Each country has its own set of regulations regarding organic production. I Brazil, the federal organization responsible for overseeing organic milk productions is the Ministério da Agricultura, Pecuária e Abastecimento - MAPA. According to the Ministério da Agricultura, Pecuária e Abastecimento [MAPA] (2011), organic dairy farms are bound to follow a set of rules, including the administration of antibiotics only in case of disease and the use of natural products when available.

Assuring the quality of the milking step is the most important aspect in the production process, and it should be properly performed to avoid milk contamination (Ruegg, 2017). The most common and one of the most effective cleaning processes involves the use of two antiseptic solutions. The first is known as "pre-dipping" and used before the milking equipment is attached to the udder or before the manual milking process to remove any dirt and contaminants. The second antiseptic solution is applied after the milking has been completed in a process known as "postdipping", cleaning and helping to protect the udder canal from bacteria. This cleaning process is important to avoid contamination of the udder by pathogenic bacteria, decreasing the chances for the development of bovine mastitis and for colonization by bacteria, thereby meeting the quality control standards (MAPA, 2018). The microbiological quality control regulation for raw milk was chosen because there are currently no regulations regarding the bacterial population on the skin of dairy cows.

Bovine mastitis is an inflammation of the udder and can be caused by a variety of microorganisms (Gomes \& Henriques, 2016). In Brazil, bovine mastitis is the cause of large economic losses for dairy farms (Lopes et al., 2012), and the most frequently isolated bacterial agents associated with bovine mastitis are Escherichia coli, Staphylococcus aureus, and Streptococcus agalactiae (Gao et al., 2019; Gomes \& Henriques, 2016; Heikkilä , Liski, Pyörälä, \& Taponen., 2018; Monistero et al., 2018).

Organic dairy farms have limited options to choose from in terms of antiseptic solutions to perform the pre-and post-dipping processes, as there are no natural antiseptics available to fulfill the organic regulation. Often, iodine is used because of the lack of a natural alternative.

Propolis-based products are constantly being developed for multiple reasons, based on properties such as antioxidative (Galeotti, Maccari, Fachini, \& Volpi, 2018) and immunomodulatory (Búfalo, Bordon-Graciani, Conti, Assis Golim, \& Sforcin, 2014) activity. Propolis also has antimicrobial properties (Przybyłek \& Karpiński, 2019), and this could potentially lead to the development of natural products in the animal field, contributing to a variety of industries such as organic milk production.

Thus, we evaluated the efficiency of a newly produced natural antiseptic solution 
based on propolis in reducing the presence of bacteria in the udder, including the main agents of bovine mastitis, to be used as an alternative on organic dairy farms while conforming to the present regulations.

\section{Materials and Methods}

\section{Sample collection}

The samples were collected from dairy cattle of the Girolando breed, between August and October 2019, on an organic dairy farm located in the city of Jaboticabal, São Paulo, Brazil.

A total of 128 samples were obtained over four periods $\left(1^{\text {st }}-4^{\text {th }}\right)$; each period consisted of 32 samples from 8 previously selected animals, 4 of which were treated as a control using the commercially available antiseptic based on iodine, namely povidoneiodine, and for the remaining 4 animals, the natural antiseptic was used, containing $1 \%$ propolis $(92 \%$ alcohol content, produced by Schraiber. Brazil, batch: 6504) in 5L of $10 \%$ hydroalcoholic solution for the predipping, and $1 \%$ propolis in $5 \mathrm{~L}$ of glycerol solution for the post-dipping. All the samples from each period were obtained from the same eight animals specified above. For the last two collection periods ( $3^{\text {rd }}$ and $4^{\text {th }}$ ), the natural antiseptic was reformulated by the manufacturer, with the addition of citronella oil as a repellent compound ( 2 drops in 1 liter of solution, produced by Destilaria Bauru, Brazil, batch: DBJM-OCT JV0167/18-1).

To verify the efficiency of the antiseptic products, the samples were collected before and after applying the antiseptic solutions to the skin of the animal. Samples collected before the dipping process yielded the current bacterial concentration on the skin, whilst samples after the application displayed the amount of bacterial reduction.

To collect the samples, sterile swabs were rubbed three times around the skin of the udder in a circular motion. The swabs were stored in tubes containing $4.5 \mathrm{~mL}$ of $0.1 \%$ peptone water (Kasvi, Brazil) and transported to the Microbiology Laboratory at the Universidade Estadual Paulista Júlio de Mesquita Filho, Faculdade de Ciências Agrárias e Veterinárias - UNESP/FCAV in thermal boxes at $5^{\circ} \mathrm{C}$ for microbiological and molecular procedures.

\section{Microbiological analysis}

Serial dilutions up to $10^{-5}$ were generated, and the samples were inoculated in MacConkey Agar and Mannitol Salt Agar (Oxoid, UK) for Enterobacteriaceae and Staphylococcus spp. colony counting, respectively. After inoculation, the media were incubated at $37^{\circ} \mathrm{C}$ for $24 \mathrm{~h}$, and the colony-forming units per $\mathrm{cm}^{2}\left(\mathrm{CFU} / \mathrm{cm}^{2}\right)$ were counted using the spread-plate protocol.

This process was repeated for each collection period, and the CFUswere compared between the two antiseptic products in terms of reduction in the total number of bacterial agents both before and after the application of the products. Following colony counting, all the samples were inoculated in Eppendorf tubes containing $500 \mu \mathrm{L}$ of $\mathrm{BHI}$ broth (Kasvi, Brazil) $+500 \mu \mathrm{L}$ of $30 \%$ glycerol and stored at $-80^{\circ} \mathrm{C}$ for future molecular analysis. 
Molecular identification of Streptococcus agalactiae

\section{DNA extraction}

For the DNA extraction, the samples were inoculated in Eppendorf tubes containing $500 \mu \mathrm{L}$ of $\mathrm{BHI}$ broth using a sterile loop and incubated at $37^{\circ} \mathrm{C}$ for $24 \mathrm{~h}$. Following the incubation, the genomic DNA was obtained using a modified protocol for genomic extraction (Kuramae, 2008). For this, $1 \mathrm{~mL}$ of bacterial culture was transferred into a $2-\mathrm{mL}$ microtube and centrifuged at 13,400 rpm and $10^{\circ} \mathrm{C}$ for 2 minutes. Subsequently, the pellet was suspended in $700 \mu \mathrm{L}$ of extraction buffer comprised of $160 \mathrm{mM}$ Tris- $\mathrm{HCl} \mathrm{pH} 8.0,50$ mM EDTA pH 8.0, $20 \mathrm{mM} \mathrm{NaCl}$ and $0.5 \%(\mathrm{w} / \mathrm{v})$ SDS, and the suspension was homogenized and incubated in a water bath at $65^{\circ} \mathrm{C}$ for 40 minutes.

Following the incubation, $300 \mu \mathrm{L}$ of $5 \mathrm{M}$ potassium acetate were added, and the solution was homogenized and incubated at $-20^{\circ} \mathrm{C}$ for 30 minutes. After incubation, 650 $\mu \mathrm{L}$ of a solution containing chloroform and isoamyl alcohol $(24: 1 \mathrm{v} / \mathrm{v})$ were added to the tube, and the samples were homogenized and centrifuged at $13,400 \mathrm{rpm}$ and $4^{\circ} \mathrm{C}$ for 10 minutes. After centrifugation, the supernatant was transferred to a new tube, and $1 \mathrm{~mL}$ of absolute ethanol was added; subsequently, the tubes were again homogenized and stored at $-20^{\circ} \mathrm{C}$ for $18 \mathrm{~h}$.

The final extraction step consisted of centrifugation of the tubes at 13,400 rpm and $10^{\circ} \mathrm{C}$ for 10 minutes. The resulting supernatant was discarded, and the sediment was allowed to airdry at room temperature for 30 minutes, followed by resuspension in $30 \mu \mathrm{L}$ of TE buffer containing $10 \mathrm{mM}$ Tris- $\mathrm{HCl} \mathrm{pH} 8.0$ and $1 \mathrm{mM}$ EDTA pH 8.0.
PCR assay

For the PCR reaction, the following calculation was used to make the PCR mix solution for one sample; the values were then multiplied by the number of samples used in each PCR reaction: $0.4 \mu \mathrm{L}$ DNTP $(10 \mathrm{mM})$, $2 \mu \mathrm{L} 10 \mathrm{X}$ buffer solution (100 mM Tris- $\mathrm{HCl}$, $500 \mathrm{mM} \mathrm{KCl}$, and $0.8 \%$ Nonidet P40), $0.8 \mu \mathrm{L}$ $\mathrm{MgCl}_{2}(25 \mathrm{mM}), 0.8 \mu \mathrm{L}$ primer (10 pM), $0.2 \mu \mathrm{L}$ (1U) Taq DNA polymerase (Fermentas Thermo Scientific, EU) and $13.8 \mu \mathrm{L}$ of molecular grade water, bringing the final volume of the solution to $18 \mu \mathrm{L}$. The final step consisted of the addition of $2 \mu \mathrm{L}$ of sample DNA, completing the mix solution for the $P C R$ reaction.

The primers used in the reaction were SAGF (5'-TAGATGGCGAATTCACTGAGA-3') and SAGR (5'-ATTGAGCAATCCCTATCACG-3'), and the cycles consisted of a first stage at $95^{\circ} \mathrm{C}$ for 2 minutes, followed by 25 cycles each comprised of a denaturation phase at $94^{\circ} \mathrm{C}$ for 30 seconds, an annealing phase at the primerspecific temperature for 45 seconds, and an extension phase at $72^{\circ} \mathrm{C}$ for 45 seconds. The final extension cycle was at $72^{\circ} \mathrm{C}$ for 7 minutes (Chiang, Pai, Chen, \& Tsen, 2008).

Following the PCR, $5 \mu \mathrm{L}$ of front dye (0.25\% bromophenol blue in $50 \%$ glycerol) were added to each amplified product. The amplified products, together with 100-bp DNA Ladder (Invitrogen, USA), were added to a $1 \%$ agarose gel containing ethidium bromide (1 $\mu \mathrm{g} / \mathrm{mL}$ ) immersed in 10X Tris-Borate-EDTA (TBE) buffer and separated by electrophoresis (90 $\mathrm{V}$ for 40 minutes). The gel was read in a transilluminator (Molecular Imager ${ }^{\circledR} \mathrm{Gel} \mathrm{Doc}^{\mathrm{TM}}$ XR System 170-8170, Bio-Rad Laboratories, USA) under UV light and photographed.

The statistical analysis was performed using the split-plot methodology, where the 
F-test was used to compare both products (control and treatment) in terms of overall reduction for all four collection periods.

\section{Results and Discussion}

We obtained a satisfactory reduction in $\mathrm{CFU} / \mathrm{cm}^{2}$ in the population of bacteria when using the natural product, achieving an antiseptic efficiency comparable to that of the iodine product in all four sample collections. This resulted in an average population of $10^{2}$ and $10^{3}$ for Enterobacteriaceae and Staphylococcus spp., respectively, after the application. The average populations of bacteria in $\mathrm{CFU} / \mathrm{cm}^{2}$ before and after the application are shown in Table 1. An improvement in the reduction of Staphylococcus spp. was observed in the second formulation of the natural product when compared to the first, as shown in Figure 1 . This is likely due to the addition of citronella oil, a natural compound with repellent properties, as shown in a study by Kongkaew, Sakunrag, Chaiyakunapruk and Tawatsin (2011), potentially decreasing udder contamination via biological vectors (Dieme et al., 2015), therefore decreasing the total population of bacteria in the sample.

\section{Table 1}

Average reduction in the populations of Enterobacteriaceae and Staphylococcus spp. for all products tested in each collection period, before and after the application

\begin{tabular}{|ccccc}
$\begin{array}{c}\text { Product used and } \\
\text { collection period }\end{array}$ & $\begin{array}{c}\text { Enterobacteriaceae } \\
\text { population } \\
\text { (Pre-dipping) } \\
\text { UFC/cm }\end{array}$ & $\begin{array}{c}\text { Enterobacteriaceae } \\
\text { population } \\
\text { (Post-dipping) } \\
\text { UFC/cm }{ }^{2}\end{array}$ & $\begin{array}{c}\text { Staphylococcus } \\
\text { spp. population } \\
\text { (Pre-dipping) } \\
\text { UFC/cm }{ }^{2}\end{array}$ & $\begin{array}{c}\text { Staphylococcus } \\
\text { spp. population } \\
\text { (Post-dipping) } \\
\text { UFC/cm }{ }^{2}\end{array}$ \\
\hline lodine $1^{\text {st }}$ period & $1.1 \times 103$ & 0 & $2.8 \times 105$ & $4.4 \times 103$ \\
\hline Propolis $1^{\text {st }}$ period & $4.2 \times 102$ & 0 & $7.2 \times 104$ & $5.9 \times 103$ \\
\hline lodine $2^{\text {nd }}$ period & $3.1 \times 102$ & 0 & $5.2 \times 103$ & $6.5 \times 102$ \\
\hline Propolis $2^{\text {nd }}$ period & $1.4 \times 103$ & $2.3 \times 102$ & $1.8 \times 104$ & $6.6 \times 103$ \\
\hline lodine $3^{\text {rd }}$ period & $5.4 \times 103$ & $2.1 \times 102$ & $3.0 \times 104$ & $2.0 \times 103$ \\
\hline Propolis $3^{\text {rd }}$ period & $1.2 \times 103$ & $1.0 \times 102$ & $1.2 \times 104$ & $1.3 \times 103$ \\
\hline lodine $4^{\text {th }}$ period & $1.2 \times 103$ & $2.0 \times 102$ & $1.6 \times 104$ & $2.9 \times 103$ \\
\hline Propolis $4^{\text {th }}$ period & $1.0 \times 103$ & $1.0 \times 102$ & $3.8 \times 104$ & $7.0 \times 103$
\end{tabular}




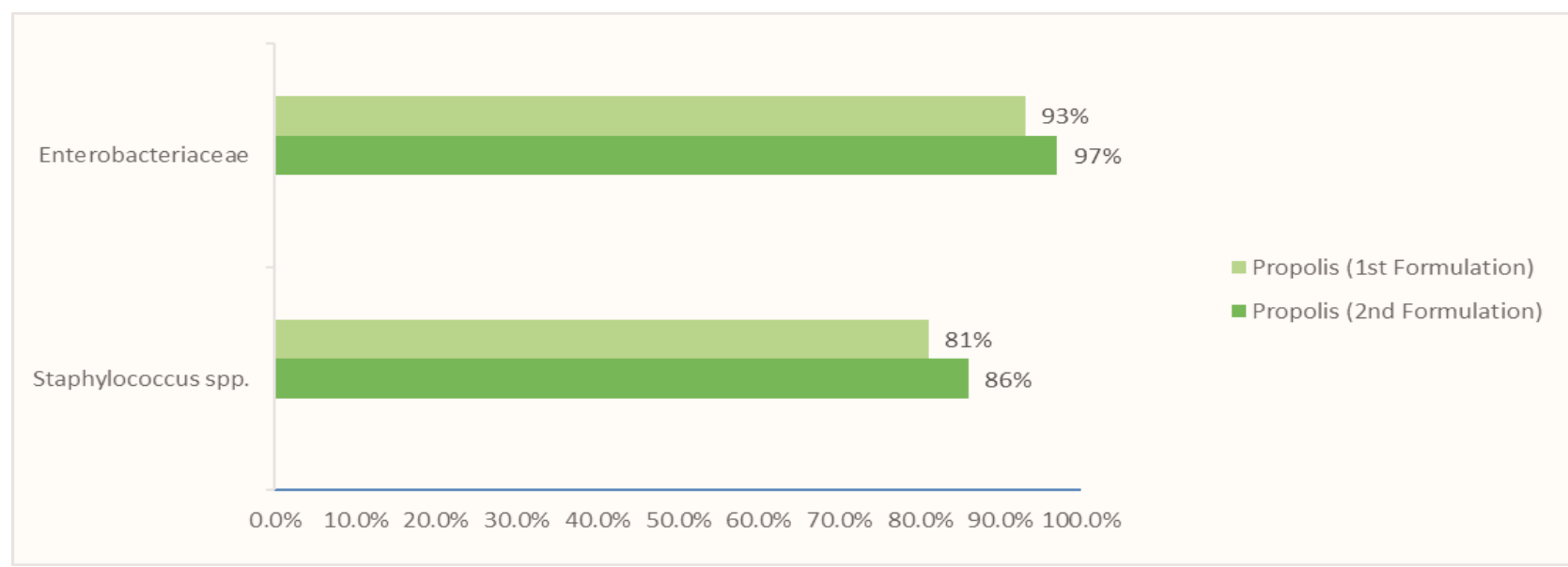

Figure 1. Comparison between both formulations of the natural propolis antiseptic in regards of total bacterial population reduction.

Enterobacteriaceae suffered a larger reduction when compared to Staphylococcus spp. for both products, often being completely eliminated after the application of the products. This result is in contrast with the findings of Sforcin (2016), where propolis showed higher antimicrobial activity against Gram-positive bacteria than Gram-negative ones, most likely because of the membrane-specific components and the production of hydrolytic enzymes by these bacteria, disrupting the components present in propolis. This difference in the results could be explained by a possible upregulation of efflux pump mechanisms of resistance by the bacteria after the products were applied (Jang, 2016), decreasing the concentrations of chemical compounds inside the bacterial cell and, consequently, decreasing the antimicrobial effect. Some studies have demonstrated this mechanism regarding different antiseptic solutions (EI Sayed Zaki, Bastawy, \& Montasser, 2019; Htun, Hon, Holden, Ang, \& Chow, 2019; Kampf, 2018). This is further supported by a study by Ignak, Nakipoglu. \& Gurler (2017), where a high prevalence for antiseptic resistance genes was found for staphylococci regarding various antiseptic compounds. Another possibility is the change in proteins of the membrane surface, granting resistance in the presence of antiseptic agents, as observed by Verspecht et al. (2019) regarding oral pathogens. A recent study by Foster (2017) has also shown a mechanism of resistance to triclosan, a biocide that, like propolis and povidone-iodine, has multiple cellular targets, indicating that a resistance mechanism to those antiseptics could be possible.

Both antiseptics used in this study have multiple mechanisms of action (Almuhayawi, 2020; McDonnell \& Denver Russell, 1999). In the case of povidone-iodine (PVP-I), a complex formed by the synthetic polymer povidone and the halogen iodine, free iodine is released into the solution and must penetrate the cell to produce an antimicrobial effect, such as oxidizing fatty acids, nucleotides, and enzymes (Bigliardi et al., 2017). 
Regarding the natural antiseptic, the reduction in the bacterial population could be justified by the multiple components in propolis with antimicrobial activity (Almuhayawi, 2020), such as flavonoids disrupting enzymatic activities (Plaper et al., 2003; Tsai et al., 2012; Veloz, Alvear, \& Salazar, 2019), phenolic compounds (Veiga et al., 2017; Yoshimasu et al., 2018), and cinnamic acids (Guzman, 2014; Vasconcelos, Croda, \& Simionatto, 2018), as well as compounds that can stimulate the immune system (Adachi et al., 2019).

Other factors regarding the less impressive reduction in Staphylococcus spp. compared to Enterobacteriaceae might include a higher concentration of Staphylococcus spp. in the samples (around $190 \%$ higher), a non-ideal concentration or contact time for Gram-positive bacteria to achieve similar reduction levels since the antiseptic solutions were pre-made and the contact time with the skin of the animals could vary during the milking process, a higher expression of intrinsic or acquired resistance mechanisms, reducing the diffusion of the antiseptic molecules into the bacterial cell (LaBreck et al., 2020), and a seasonal variation of the natural propolis; since the collection of the samples spammed a period of a few months, the variation in the climate could have affected the local flora, consequently altering structures within the propolis and therefore modifying its antimicrobial activity (Castro et al., 2007; Pina et al., 2017).

Regarding Streptococcus agalactiae identification, molecular analysis using PCR was negative for all 128 samples. The absence of $S$. agalactiae is in agreement with the conditions found in this study, since all animals studied neither showed any clinical signs of mastitis nor a reduction in milk production, suggesting that subclinical mastitis was unlikely (Ashraf \& Imran, 2018; Lakew, Fayera, \& Ali, 2019).

The statistical analysis showed no significant difference in the overall reduction between both products tested, for both Enterobacteriaceae and Staphylococcus spp. in pre and post-dipping processes (Table 2). This result indicates that both products showed similar level of bacterial reduction after application, strengthening the idea of propolis and citronella as viable natural alternatives for being used in antiseptic solutions, achieving similar results to iodine products. 


\section{Table 2}

F-test results showing the reduction level between the iodine and propolis-citronella products to be overall not statistically significant, for both Enterobacteriaceae and Staphylococcus spp. in each collection period

\begin{tabular}{|c|c|c|c|c|c|c|c|c|c|c|c|}
\hline \multicolumn{6}{|c|}{ Enterobacteriaceae pre-dipping F-test } & \multicolumn{6}{|c|}{ Enterobacteriaceae post-dipping F-test } \\
\hline Variance & DF & SS & MS & $\mathrm{F}$ & $\mathrm{P}$ & Variance & DF & SS & MS & $\mathrm{F}$ & $P$ \\
\hline $\begin{array}{l}\text { lodine w. } \\
\text { Propolis } 1 c^{*}\end{array}$ & 1 & $1.8 \times 10^{10}$ & $1.8 \times 10^{10}$ & $0.07^{\mathrm{NS}}$ & 0.7889 & $\begin{array}{l}\text { lodine w. } \\
\text { Propolis 1c }\end{array}$ & 1 & 0 & 0 & $\varnothing$ & $\varnothing$ \\
\hline $\begin{array}{l}\text { lodine w. } \\
\text { Propolis 2c }\end{array}$ & 1 & $5.4 \times 10^{10}$ & $5.4 \times 10^{10}$ & $0.21^{\mathrm{NS}}$ & 0.6449 & $\begin{array}{c}\text { lodine w. } \\
\text { Propolis 2c }\end{array}$ & 1 & $2.2 \times 10^{10}$ & $2.2 \times 10^{10}$ & 4.51 & 0.0382 \\
\hline $\begin{array}{l}\text { lodine w. } \\
\text { Propolis 3c }\end{array}$ & 1 & $7.1 \times 10^{9}$ & $7.1 \times 10^{9}$ & $2.82^{\mathrm{NS}}$ & 0.0988 & $\begin{array}{c}\text { lodine w. } \\
\text { Propolis 3c }\end{array}$ & 1 & $7.5 \times 10^{10}$ & $7.5 \times 10^{10}$ & $0.02^{\mathrm{NS}}$ & 0.9026 \\
\hline $\begin{array}{l}\text { Iodine w. } \\
\text { Propolis 4c }\end{array}$ & 1 & $1.2 \times 10^{10}$ & $1.2 \times 10^{10}$ & $0.05^{\mathrm{NS}}$ & 0.8273 & $\begin{array}{l}\text { Iodine w. } \\
\text { Propolis } 4 \mathrm{c}\end{array}$ & 1 & $2.2 \times 10^{10}$ & $2.2 \times 10^{10}$ & $0.45^{\mathrm{NS}}$ & 0.5052 \\
\hline
\end{tabular}

\begin{tabular}{|c|c|c|c|c|c|c|c|c|c|c|c|}
\hline \multicolumn{6}{|c|}{ Staphylococcus spp. pre-dipping F-test } & \multicolumn{6}{|c|}{ Staphylococcus spp. post-dipping F-test } \\
\hline Variance & DF & ss & MS & $\mathrm{F}$ & $P$ & Variance & DF & SS & MS & $\mathrm{F}$ & $P$ \\
\hline $\begin{array}{l}\text { Iodine w. } \\
\text { Propolis 1c }\end{array}$ & 1 & $1.7 \times 10^{11}$ & $1.7 \times 10^{11}$ & 7.11 & 0.01 & $\begin{array}{l}\text { lodine w. } \\
\text { Propolis 1c }\end{array}$ & 1 & $8.1 \times 10^{10}$ & $8.1 \times 10^{10}$ & $0.15^{\mathrm{NS}}$ & 0.701 \\
\hline $\begin{array}{l}\text { Iodine w. } \\
\text { Propolis 2c }\end{array}$ & 1 & $6.8 \times 10^{10}$ & $6.8 \times 10^{10}$ & $0.03^{\mathrm{NS}}$ & 0.8693 & $\begin{array}{l}\text { Iodine w. } \\
\text { Propolis 2c }\end{array}$ & 1 & $1.4 \times 10^{10}$ & $1.4 \times 10^{10}$ & $2.67^{\mathrm{NS}}$ & 0.1077 \\
\hline $\begin{array}{l}\text { lodine w. } \\
\text { Propolis 3c }\end{array}$ & 1 & $6.4 \times 10^{10}$ & $6.4 \times 10^{10}$ & $0.03^{\mathrm{NS}}$ & 0.873 & $\begin{array}{l}\text { lodine w. } \\
\text { Propolis 3c }\end{array}$ & 1 & $1.8 \times 10^{10}$ & $1.8 \times 10^{10}$ & $0.03^{\mathrm{NS}}$ & 0.853 \\
\hline $\begin{array}{l}\text { lodine w. } \\
\text { Propolis 4c }\end{array}$ & 1 & $1.9 \times 10^{10}$ & $1.9 \times 10^{10}$ & $0.08^{\mathrm{NS}}$ & 0.7802 & $\begin{array}{c}\text { Iodine w. } \\
\text { Propolis 4c }\end{array}$ & 1 & $6.5 \times 10^{10}$ & $6.5 \times 10^{10}$ & $1.20^{\mathrm{NS}}$ & 0.2775 \\
\hline
\end{tabular}

${ }^{*} \mathrm{C}=$ collection period, 1 st to 4 th

$\mathrm{DF}=$ Degress of Freedom

$\mathrm{SS}=$ Sum of Squares

MS = Mean Square

NS = Statistically non-significant

\section{Conclusions}

The natural product using propolis and citronella showed a great overall antiseptic efficiency, comparable to that of iodine products. This is an important finding for organic dairy farms, since the main antiseptic being currently used is iodine-based, and a natural alternative with similar efficiency could greatly encourage organic milk production.

\section{Acknowledgments}

The authors are grateful for the graduate scholarship provided as financial aid by the Coordenação de Aperfeiçoamento de Pessoal de Nível Superior (CAPES) - Finance Code 001, Process Number: 88882.433645/2019-01 


\section{References}

Adachi, T., Yoshikawa, S., Tezuka, H., Tsuji, N. M., Ohteki, T., Karasuyama, H., \& Kumazawa, T. (2019). Propolis induces $\mathrm{Ca}^{2+}$ signaling in immune cells. Bioscience of Microbiota, Food and Health, 38(4), 141-149. doi: 10.12938/bmfh.19-011

Almuhayawi, M. S. (2020). Propolis as a novel antibacterial agent. Saudi Journal of Biological Sciences, 27(11), 3079-3086. doi: 10.1016/j.sjbs.2020.09.016

Ashraf, A., \& Imran, M. (2018). Diagnosis of bovine mastitis: from laboratory to farm. Tropical Animal Health and Production, 50(6), 1193-1202. doi: 10.1007/s11250018-1629-0

Bigliardi, P. L., Alsagoff, S. A. L., El-Kafrawi, H. Y., Pyon, J. K., Wa, C. T. C., \& Villa, M. A. (2017). Povidone iodine in wound healing: A review of current concepts and practices. International Journal of Surgery, 44(1), 260-268. doi: 10.1016/j. ijsu.2017.06.073

Búfalo, M. C., Bordon-Graciani, A. P., Conti, B. J., Assis Golim, M. de, \& Sforcin, J. M. (2014). The immunomodulatory effect of propolis on receptors expression, cytokine production and fungicidal activity of human monocytes. Journal of Pharmacy and Pharmacology, 66(10), 1497-1504. doi: 10.1111/jphp.12279

Castro, M.L., Cury, J. A., Rosalen, P.L., Alencar, S. M., Ikegaki, M., Duarte, S., \& Koo, H. (2007). Própolis do sudeste e nordeste do Brasil: Influência da sazonalidade na atividade antibacteriana e composição fenólica. Quimica Nova, 30(7), 1512-1516. doi: 10.1590/S0100-40422007000700003
Chiang, Y. C., Pai, W. Y., Chen, C. Y., \& Tsen, H. Y. (2008). Use of primers based on the heat shock protein genes hsp70, hsp40, and hsp10, for the detection of bovine mastitis pathogens Streptococcus agalactiae, Streptococcus uberis and Streptococcus bovis. Molecular and Cellular Probes, 22(4), 262-266. doi: 10. 1016/j.mcp.2008.05.004

Dieme, C., Bechah, Y., Socolovschi, C., Audoly, G., Berenger, J. M., Faye, O.,... Parola, P. (2015). Transmission potential of rickettsia felis infection by Anopheles gambiae mosquitoes. Proceedings of the National Academy of Sciences of the United States of America, 112(26), 80888093. doi: 10.1073/pnas.1413835112

El Sayed Zaki, M., Bastawy, S., \& Montasser, K. (2019). Molecular study of resistance of Staphylococcus aureus to antiseptic quaternary ammonium compounds. Journal of Global Antimicrobial Resistance, 17(1), 94-97. doi: 10.1016/j. jgar.2018.11.022

Foster, T. J. (2017). Antibiotic resistance in Staphylococcus aureus. Current status and future prospects. FEMS Microbiology Reviews, 41(3), 430-449. doi: 10.1093/ femsre/fux007

Galeotti, F., Maccari, F., Fachini, A., \& Volpi, N. (2018). Chemical composition and antioxidant activity of propolis prepared in different forms and in different solvents useful for finished products. Foods, 7(3), 41. doi: 10.3390/foods7030041

Gao, X., Fan, C., Zhang, Z., Li, S., Xu, C., Zhao, Y., Liu, M. (2019). Enterococcal isolates from bovine subclinical and clinical mastitis: antimicrobial resistance and integron- 
gene cassette distribution. Microbial Pathogenesis, 129(2018), 82-87. doi: 10.1016/j.micpath.2019.01.031

Gomes, F., \& Henriques, M. (2016). Control of bovine mastitis: old and recent therapeutic approaches. Current Microbiology, 72(4), 377-382. doi: 10.10 07/s00284-015-09 58-8

Guzman, J. D. (2014). Natural cinnamic acids, synthetic derivatives and hybrids with antimicrobial activity. Molecules, 19(12), 19292-19349. doi: 10.3390/ molecules191219292

Heikkilä, A. M., Liski, E., Pyörälä, S., \& Taponen, S. (2018). Pathogen-specific production losses in bovine mastitis. Journal of Dairy Science, 101(10), 9493-9504. doi: 10.3168/jds.2018-14824

Htun, H. L., Hon, P. Y., Holden, M. T. G., Ang, B., \& Chow, A. (2019). Chlorhexidine and octenidine use, carriage of qac genes, and reduced antiseptic susceptibility in methicillin-resistant Staphylococcus aureus isolates from a healthcare network. Clinical Microbiology and Infection, 25(9), 1154.e1-1154.e7. doi: 10. 1016/j.cmi.2018.12.036

Ignak, S., Nakipoglu, Y., \& Gurler, B. (2017). Frequency of antiseptic resistance genes in clinical staphycocci and enterococci isolates in Turkey. Antimicrobial Resistance and Infection Control, 6(1), 66-68. doi: 10.1186/s13756-017-0244-6

Jang, S. (2016). Multidrug efflux pumps in Staphylococcus aureus and their clinical implications. Journal of Microbiology, 54(1), 1-8. doi: 10.1007/s12275-016-51 $59-z$
Kampf, G. (2018). Adaptive microbial response to low-level benzalkonium chloride exposure. Journal of Hospital Infection, 100(3), e1-e22. doi: 10.1016/j. jhin.2018.05.019

Kongkaew, C., Sakunrag, I., Chaiyakunapruk, N., \& Tawatsin, A. (2011). Effectiveness of citronella preparations in preventing mosquito bites: Systematic review of controlled laboratory experimental studies. Tropical Medicine and International Health, 16(7), 802-810. doi: 10.1111/j.1365-3156.2011.02781.x

Kuramae, E. (2008). A rapid, easy and high yield protocol for total genomic dna isolation of Colletotrichum gloeosporioides and Fusarium oxysporum. Revista Universidade Estadual de Maringá, 19(3), 683-689. Retrieved from https:// www.researchgate.net/publication/2771 53225

LaBreck, P. T., Bochi-Layec, A. C., Stanbro, J., Dabbah-Krancher, G., Simons, M. P., \& Merrell, D. S. (2020). Systematic analysis of efflux pump-mediated antiseptic resistance in Staphylococcus aureus suggests a need for greater antiseptic stewardship. MSphere, 5(1), e00959-19. doi: 10.1128/msphere.00959-19

Lakew, B. T., Fayera, T., \& Ali, Y. M. (2019). Risk factors for bovine mastitis with the isolation and identification of Streptococcus agalactiae from farms in and around Haramaya district, eastern Ethiopia. Tropical Animal Health and Production, 51(6), 1507-1513. doi: 10.10 07/s11250-019-01838-w 
Lopes, M. A., Demeu, F. A., Rocha, C. M. B. M. da, Costa, G. M. da, Franco, A., Neto, \& Santos, G. dos. (2012). Avaliação do impacto econômico da mastite em rebanhos bovinos leiteiros. Arquivos do Instituto Biológico, 79(4), 477-483. doi: 10.1590/s1808-16572012000400003

Ministério da Agricultura, Pecuária e Abastecimento (2011). Instrução Normativa no 46, de 6 de outubro de 2011. Regulamento Técnico para os Sistemas Orgânicos de Produção Animal e Vegetal. Diário Oficial da União, Brasília, DF, 7 out. 2011, Seção 1, 4-12.

Ministério da Agricultura, Pecuária e Abastecimento (2018). Instrução Normativa $n^{\circ} 76$, de 26 de novembro de 2018. Regulamento Técnico de Identidade e Qualidade de Leite Cru Refrigerado. Diário Oficial da União, Brasília, DF, 26 Nov. 2018, Seção 1, 1-9.

McDonnell, G., \& Denver Russell, A. (1999). Antiseptics and disinfectants: activity, action, and resistance. Clinical Microbiology Reviews, 12(1), 147-179. doi: 10.1128/CMR.12.1.147

Monistero, V., Graber, H. U., Pollera, C., Cremonesi, P., Castiglioni, B., Bottini, E.,... Moroni, P. (2018). Staphylococcus aureus isolates from bovine mastitis in eight countries: genotypes, detection of genes encoding different toxins and other virulence genes. Toxins, 10(6), 247. doi: 10.3390/toxins 10060247

Pina, R., Silva, D., Aparecida, B., Machado, S., De, G., Barreto, A.,... Umsza-guez, M. A. (2017). Cytotoxic properties of various Brazilian propolis extracts. PLoS ONE, 12(3), 1-18. doi:10.1371/journal. pone.0172 585
Plaper, A., Golob, M., Hafner, I., Oblak, M., Šolmajer, T., \& Jerala, R. (2003). Characterization of quercetin binding site on DNA gyrase. Biochemical and Biophysical Research Communications, 306(2), 530-536. doi: 10.1016/S0006291X(03)01006-4

Przybyłek, I., \& Karpiński, T. M. (2019). Antibacterial properties of propolis. Molecules, 24(11), 11-13. doi: 10.3390/ molecules 24112047

Ruegg, P. L. (2017). A 100-year review: mastitis detection, management, and prevention. Journal of Dairy Science, 100(12), 1038110397. doi: 10.3168/jds.2017-13023

Sforcin, J. M. (2016). Biological properties and therapeutic applications of propolis. Phytotherapy Research, 30(6), 894-905. doi: 10.1002/ptr.5605

Tsai, Y. C., Wang, Y. H., Liou, C. C., Lin, Y. C., Huang, H., \& Liu, Y. C. (2012). Induction of oxidative DNA damage by flavonoids of propolis: Its mechanism and implication about antioxidant capacity. Chemical Research in Toxicology, 25(1), 191-196. doi: $10.1021 / \mathrm{tx} 200418 \mathrm{k}$

Vasconcelos, N. G., Croda, J., \& Simionatto, S. (2018). Antibacterial mechanisms of cinnamon and its constituents: a review. Microbial Pathogenesis, 120(1), 198-203. doi: 10.1016/j.micpath.2018.04.036

Veiga, R. S., Mendonça, S. de, Mendes, P. B., Paulino, N., Mimica, M. J., Lagareiro, A. A., Netto,... Marcucci, M. C. (2017). Artepillin $\mathrm{C}$ and phenolic compounds responsible for antimicrobial and antioxidant activity of green propolis and Baccharis dracunculifolia DC. Journal of Applied Microbiology, 122(4), 911-920. doi: 10. 1111/jam.13400 
Veloz, J. J., Alvear, M., \& Salazar, L. A. (2019). Antimicrobial and antibiofilm activity against Streptococcus mutans of individual and mixtures of the main polyphenolic compounds found in chilean propolis. BioMed Research International, 2019(1), 1-7. doi: 10.1155/2019/7602343

Verspecht, T., Rodriguez Herrero, E., Khodaparast, L., Khodaparast, L., Boon, N., Bernaerts, K.,... Teughels, W. (2019). Development of antiseptic adaptation and cross-adapatation in selected oral pathogens in vitro. Scientific Reports, 9(1), 1-13. doi: 10.1038/s41598-019-44 822-y

Yoshimasu, Y., Ikeda, T., Sakai, N., Yagi, A., Hirayama, S., Morinaga, Y.,... Nakao, R. (2018).Rapidbactericidalactionofpropolis against Porphyromonas gingivalis. Journal of Dental Research, 97(8), 928936. doi: 10.1177/0022034518758034 
